\title{
Matoš and Whitman: a Comparison of Two Poems
}

\begin{abstract}
Mitrovich Ksenija, Swanson Martha, Matoš and Whitman: a Comparison of Two Poems. „Poznańskie Studia Slawistyczne” 7. Poznań 2014. Publishing House Science and Innovate, pp. 285-295. ISBN 978-83-63795-79-5. ISSN 2084-3011.

This essay compares Utjeha kose, translated as The Solace of Hair, by Antun Gustav Matoš and Death's Valley by Walt Whitman. We analyze similarities in theme, metaphor and poetic style. We also offer a close analysis of verse, together with meter, together with syntax and phonology of the two poems. Matoš and Whitman approach similar themes from different perspectives. However, we find coincidental similarities in both techniques and stylistic devices and the underlying messages of the pieces. We also draw upon our personal vision of the pieces as well as, in the case of Death's Valley in particular, outside sources, to form our opinions. It is necessary to say that we had no access to any materials on Matoš, and, therefore, all our statements on The Solace of Hair are our personal conclusions and have no intext or works cited documentation.
\end{abstract}

Keywords: Antun Gustav Matoš; Whitman; death in poetry; iambic hexameter; alexandrine; Italian sonnets; free verse; phonetic properties; inversion

I stared at you last night. Asleep. Dejected. Dead.

In hall dark, ominous, in idyll full of bloom,

On elevated bier, midst candlelighted gloom,

Resolv'd to sacrifice my own long life instead. 
I didn't cry. Did not. Just stopped, too stunned, like stone, In hall dark, ominous, yet full of death so dear, In doubt the eyes once dark this night would still be clear, from which for me alas a better life once shone.

All dead indeed, all dead: the eyes, the breath, the hands, All that desperately I wished I could restore, In blinding agony, at frenzied woe's commands.

In hall dark, ominous, in thoughts all gray and sore, Your hair alone was though the one last shred alive, And said: Be at peace. In death indeed dreams thrive.

The Solace of Hair, Antun Gustav Matoš ${ }^{1}$

This essay compares two poems, Death's Valley by Walt Whitman and The Solace of Hair by Antun Gustav Matoš. The idea to compare the two poems was born during the work on the translation of Matoš's poem and through a contextual approach confirming this poem's landmark position in Croatian literature. This made us draw an analogy with W. Whitman and his position in the history of American literature.

Matoš is an example of a writer who originated in the most democratic class of people, the one which fights for the masses against destructive ideologies and mass psychology and therefore finds itself on the other side of the barricades held by conservatives (Donat 1986: 12).

In other words:

Generally speaking, democracy for Whitman was above all a personal quality legalized trough individualism, interactions of individuals (identity) as well as individuals and the society as a whole (Whitman 2002: 741).

This political analogy motivated us to try to make a textual comparison of two particular texts of these two authors, a comparison of a Whitman poem with the poem by Matoš on whose translation one of us had already

\footnotetext{
1 Translated by Ksenija Mitrovich.
} 
worked. Of course, it was not necessary to insist on their closeness, but one of the common themes in poetry in general, the theme of death, afforded the opportunity to find a few similar semantic motives among many different ones. Therefore, in order to find a strong initial similarity in this narrow overlap, the theme of death, it was crucial to find a poem by Whitman that is visually more contained and limited than his other, commonly more visually expansive works. Matoš's poem, with its introspective and spatially inclusive representation of the state of dreams, was our starting and ending point of reference since it was the subject of the translation. To aid in this process, we chose the poem by Whitman that has been tied to a particular visual artwork since the poem's publication and in later interpretations. Namely, a painting by George Inness in which the dark center is superimposed against a lighter background paradoxically internalizes Whitman's lines, captures the image of light in them and points toward the metaphysical. Innes was the painter of the spirituality of the landscape, and Whitman answered with the landscape of humanism. It would be more effective to include Matoš in this three-way comparison, but it would significantly stretch the limits of this work. In any case, when compared, Whitman's idea of welcome death and Matoš's idea of solace in death both measure against the Biblical title of Innes' painting (The Valley of the Shadow of Death).

Contemporary approaches to the two authors suggest similarities, initially with their texts and additionally in the literary historical sense within each respective national literature. For example, in his writings on Croatian expressionism, Donat views Matoš's poetry as an anticipation and beginning of this literary period. He claims, „In Croatian poetry, Matoš's poem The Nightmare is the landmark, the point at which the conversation of the past stops, and communication rich with poetic idioms of the future begins" (Donat 2001: 443). In addition, Suško, pondering the subjects of physicality of human body and death, writes, ,inviting others to step into the unknown together (...). Whitman really takes on the role of the «tutor» and the «prophet»" (Whitman 2002: 755).

The dominant Croatian literary critic from the end of the twentieth century, Branimir Donat, as well as the most prolific and critically knowledgeable translator of Whitman into Croatian, Mario Suško, claim that Matoš and Whitman, both summed up and cancelled (Donat: 2001: 443) the past of the respective national literary output (Donat 1986: 12), re-worked it, authorized it, and with the use of certain poetic-democratic devices 
transformed it into an influential body of national literary future (Whitman 2002: 741, 755). The months-long work on the translation of Matoš's poem The Solace of Hair resulted in the awareness of how much the poetic images and completely diverse experimentation with metric innovations are contrasted.

We started this work with the translation that led to the essay, and next we proceeded with the results that the comparison of the two poems yielded.

\section{2.}

A.G. Matoš and W. Whitman, equal in notoriety in their respective countries but separated by time and space, are nonetheless poets who share some thematic and formal similarities in their writing. Their lifetimes overlapped by only nineteen years before Whitman passed away. Matoš obviously read Whitman's work since in From Samobor, he states metaphorically that, „Whitman and Verlaine wander along sunny and adventurous roads" (Matoš 1994: 80), suggesting not only familiarity with Whitman's work but an informed opinion about it as well. The thematic and formal similarities of these two poets, as well as differences, become obvious if two works that each author wrote later in his life are juxtaposed: Matoš's poem Utjeha kose, translated as The Solace of Hair, written in 1906, eight years before the poet died, and Whitman's poem Death's Valley, published in 1892, a month after the poet passed away (Whitman 1892: 707).

\section{3.}

The most obvious point of convergence of these two poems is the central theme in each - the phenomenon of death and the eternal mystery of its nature. The two poems, however, do not share a similar attitude until their ends. Only the last line of The Solace of Hair matches the sentiment present throughout Death's Valley. Namely, Matoš's poem on death, The Solace of Hair, starts as an observation by the narrator of an individual instance of death, the demise of a familiar person and, for the most part, continues 
as a lamentation over personal loss and inner turmoil. In the first stanza, death is presented as a final and irreversible horror, a loss from which there is no release. Death came unexpectedly; it was neither predicted nor welcome and, throughout most of the poem, apparently does not bring relief either to the deceased or to the bereaved. In the very first line, the reader is accosted by, „Asleep. Dejected. Dead”. Through the skillful manipulation of the syntax, rhythm, and phonetic qualities of Croatian consonants, the narrator strips himself down to raw emotion. The words, such as ,dejected, dead, ominous, bier, and agony", paint a gloomy picture of this particular experience. The powerful description of the awe-inspiring but terrifying scene in the morgue is laden with heavy emotional intensity, which enables the reader to identify with the narrator. Terse sentences, consisting of only one word, pessimistic adjectives (dead, ominous, stunned, blind), and many hard consonants set the mood in most of the poem. In other words, from the onset, the poem is fertile grounds for its readership's empathy. The narrator in Death's Valley, on the other hand, sings praises to death as a spiritually uplifting and rewarding experience when compared to human suffering. There is neither shock nor despair but rather a welcome release from the life of struggles, a welcome respite. While in The Solace of Hair, suffering is personal, and the one who has suffered is not the dead person, but the one who misses her, in Death's Valley, suffering is communal and universal, relieved finally by the beautiful and welcome death. While in the latter poem the narrator rejoices because death is so generous, in the first one the narrator does not rejoice at all but rather goes through a typical grieving process - the five stages of grief and loss containing shock, fear, depression, anger, bargaining, and acceptance. Thus, in a way, Whitman's poem negates the tragedy of death, pronouncing it just an eventual stage in everyone's life; in this view, all individual lives have equal value. Matoš's poem, on the other hand, presents the experience of death as a very personal one, thus assigning greater value to each individual existence. While Death's Valley communicates that everyone should expect ease and beauty from death, most of The Solace of Hair laments personal loss. Death, a common topic in art, yet one with a general pessimistic promise, therefore requires a truly fresh or unusual approach to evoke awe in a new piece. Since death has been subject in art throughout human history, an original formal and semantic execution is more effective in arousing such interest. In the case of these 
two poems, Matoš's poem surprises with an unexpected closing line. The fact that most of the poem is a dream sequence with an element of a fable, namely, hair having the faculty of speech, allows the poem to change from utterly gloomy to peaceful. Whereas there is not much surprise in Death's Valley since the positive position on death is clear from the beginning, in the last line of The Solace of Hair, the gloomy mourning mood morphs into a state of pacified calm.

The Solace of Hair and Death's Valley have the same topic, death, but their similarity also resides in the answer to questions about existence after physical death. In both poems, human loss is comforted by the idea of a continuation in the metaphysical realm, through dreams or in a dream-like place. In The Solace of Hair, the narrator finds the solution to his grief at the very end; he realizes in his dream, a metaphysical state of mind, that rather than being an absolute end, death is an alternate state of being in which dreams continue their journey, and so does the dreamer. Dreaming, a metaphor for the creative force necessary for a meaningful existence, in this poem provides the hope for the continuation of life in a form with which humanity can identify. In Death's Valley, however, the narrator extols praise on death as a permanent anesthetic and as a state of heavenly bliss for all humans. Whitman's narrator finds solace on a grand scheme, in the all-encompassing religion, with God as the creative force, but Matoš's narrator finds solace only in the possibility of a dream. The Solace of Hair provides closure in the line, „Be at peace. In death indeed dreams thrive”, while Death's Valley ends with, „Sweet, peaceful, welcome Death”. Both narrators find comfort in death and express beliefs in some sort of afterlife.

Although Matoš and Whitman share the theme of death, their poetic formats are very different. In the case of these two poems, The Solace of Hair is more conservative and commands more control, while Death's Valley is more liberal and playful. Matoš was dedicated to the form of the traditional sonnet and thus very intentional with his rhyme and meter. The Solace of Hair is written in iambic hexameter, an alexandrine (Casale 2010: 49); each line contains two groups of six syllables in an unstressed-stressed pattern separated by a caesura. The rhyme is equally deliberate. Each of the first two stanzas following the same rhyme scheme (ABBA) and the final two stanzas act as a sestet. This would classify Matoš's The Solace of Hair as akin to the traditional Italian sonnet (Miller), which either reflects his 
dedication to formal sonnet writing or his desire to challenge himself as a poet. Petrarch might have scoffed at the presence of a couplet in the last stanza, which is typical of a Shakespearian sonnet. The two last lines rhyme contributes to a powerful change of direction after the volta (Miller). Our English translation of Matoš's work follows his original rhyme scheme and sonnet pattern that is present in the Croatian. In stark contrast, Whitman is famous as the first American, influential practitioner of free verse and the first to experiment fully with the artistic possibilities that form allowed" (Casale 2010: 53). Whitman's Death's Valley contains beautiful and descriptive imagery, but it does not rhyme. If it is read out loud, it is more evocative of prose than poetry because the lines do not have consistent lengths, and there is a lack of predictable melody to his writing. Therefore, discovering the rhythm is up to the reader, who can select to become an active participant in the unveiling of the poem at each reading (Casale 2010: 47). In The Solace of Hair, the reader can be emotionally active but otherwise passive. Actually, the carefully constructed form does not allow any space for guesswork. Its form is perfect; the poem is optimally furnished and presented as finite. In contrast, in Death's Valley, the lines consist of phrases rather than iambic feet that are present in Matoš's poetry. The „organic rhythms of his irregular, wave like lines" (Killingsworth 2007: 113) hint at freedom of mind and physical movement. This liberal treatment of the verses does not mean that there is no design to Whitman's poetry. The phrases are carefully arranged; anaphora at the beginnings of some lines, particularly coordinating conjunctions ,,and" and ,nor”, attest to careful planning. A similar effect is produced in The Solace of Hair with the use of the preposition ,in" at the beginnings of four lines. In Death's Valley, six lines begin with the front vowel [æ] and three with the nasal consonant [n]. Repetition in this position gives especially Whitman's poem a semblance to a chant. Whitman's poetry style, written in free verse is similar to the rhythm of the Bible verses. This gives the poem a feeling of structural lightness and the narrator an almost visionary character. In addition, an invocation of God adds fitting theatricality to the topic of religious enlightenment. In The Solace of Hair, there is no invocation or mention of a divine being. The narrator is definitely a plain human being who suffers human troubles alone.

One of the similarities in The Solace of Hair and in Death's Valley is the technique of enumeration. In The Solace of Hair, for example in „Asleep. 
Dejected. Dead”, or „the eyes, the hands, the breath”, it is used to a lesser degree since the sonnet is necessarily more economical with the number of syllables in a line as well as the total number of lines. In Death's Valley, it is plentiful in the second stanza (soldiers, nurses, doctors, the old, the infant, the rich, the poor). In one line, the enumerated nouns are semantically juxtaposed, the old, the infant; the rich, the poor). Another interesting syntactic characteristic of both poems is the particular use or lack of verbs, respectively. While Matoš uses verbs for their phonetic and semantic qualities, Whitman is very frugal with them. In the whole second stanza of Death's Valley, consisting of seven lines, there are only six verbs. Angus Fletcher states about that poem that, ,the poet's «nominal style» employs a coupling of nouns with adjectives or participles, without benefit of finite verbs or copulas" (Fletcher 2006: 216), as in the line:

Of the broad blessed light and perfect air, with meadows, rippling tides, and trees And flowers and grass,

And of the low hum of living breeze-and in the midst God's beautiful eternal right hand

Thee, holiest minister of Heaven-thee, envoy, usherer guide of last of all, Rich, florid, loosener of the stricture-knot called life (Death's Valley, Whitman 1892: 707).

Still, in spite of the small numbers of verbs, Whitman's poem sounds more like an epic poem than Matoš does due to the more prose-like quality of the free verse. In addition, Death's Valley includes references to social conditions and events, so removing active verbs actually helps soften the epic quality that otherwise might be present in such a style. The floral focus on description, rather than on action, adds to the effective grandeur.

One obvious similarity between Death's Valley and The Solace of Hair is skillful use of phonetic properties of each language. Aside from the expressions of invocation, most vocabulary in Death's Valley consists of everyday words. The same is true of The Solace of Hair. However, the frequent use of alliteration manipulates the mood in both poems. In The Solace of Hair the repetition of the hard Croatian fricative sound [ $\check{z}]$ in the original, ,život kao žrtvu", hints at disappointment and bitterness. The voiceless fricative continuous sound [s], as in ,u slijepoj stravi i u strasti” is, in fact, used twenty six times throughout the poem, evoking the occasional sizzle of dripping candlewicks 
as they undergo their own agony. It is also a continuant sound, adding the element of a process, as in the passage of eternal time. Whitman also employs [s], for example in, ,a scene, a song”, or in ,celebrate the struggle”, which sound happy in English, and the oral glide [r], softer in English than in Croatian but nonetheless hard, as in, „Rich, florid, loosener of stricture-knot” for stronger rhythm. In The Solace of Hair, the frequent use of Croatian strenuous frontal rolled trill $[\mathrm{r}]$ in consonant clusters signals hardness and the horrified rigidity of the narrator (,mrtvu, žrtvu, smrti, stravi, strasti”). On the other hand, the soft palatal [j] (,punoj, jasne, sjao, htjedoh, miruj”) offers counterbalance to these sharp consonants and the welcome temporary relief from the strain. Similarly, in Death's Valley, the frequent repetition of the long front vowel [i] gives the poem a pleasant aural element of ease and peace (,dream, theme, thee, seen, these, scene, brief, trees, breeze sweet, peaceful"), which reinforces the narrator's interpretation of death as one of relief and ease rather than suffering and torment (Alterbaum 2003: 118, 157, 280, 294, 312).

There is another unusual literary technique in the writing styles of both poets. The best example of this is the inversion of the formal adjective and noun word order. Matošss repeatedly uses ,hall ominous” even though in standard, grammatically correct Croatian one places adjectives before nouns. Whitman refers to ,designer dark” and a ,song brief” when standard English requires adjectives to come before the nouns as well. For Whitman, it may have been a question of experimentation and break with the tradition, while for Matoš it may have fit better within the foot of the sonnet. Yet, regardless of the motive, each poet was very successful at creating a strong emotional impact with this technique.

Physical spaces described in the two poems are different but equally important. The Solace of Hair takes place in a very small, dim, confined space - the morgue. The ominousness of such a space is juxtaposed to the beauty of floral arrangements, which are as temporary as human life. The only light comes from the flickering candles, an image visually beautiful and peaceful but eerily reminiscent of sorrow. Their own presence drips away in ,woe of candlelight". This inevitability is agonizing for the narrator, but even in his grief, he is still aware of the solemn beauty of the scene. The description emphasizes the duality in human lives - the presence of death in life. However, in Death's Valley the space a dead person enters is broad and wide open, bright with heavenly light and rich with nature. This image serves its own 
purpose: to glorify death. In his introduction to Leaves of Grass, Gay Wilson Allen says that Whitman actually ,searched always for some profound truth residing or emanating from external form" (Allen 1980: XI), i.e. bliss from the idyllic natural scene. These images ,perpetuate the momentary impressions" (Fletcher 2006: 216) and offer glimpses into the welcome heaven.

4.

Despite the geographical and cultural differences between A.G. Matoš and W. Whitman, they wrote on similar themes and applied some similar techniques in their poems The Solace of Hair and Death's Valley. While Whitman and Matoš share themes in their writing, Matoš accomplishes the truly amazing feat of being both more formal and precise in his poetry and also less pretentious. While Whitman often uses grandiose vocabulary and subjects in his poetry, Matoš achieves equally extraordinary effects with seemingly ordinary vocabulary. As Whitman's speaker views death from the enlightened perch of wisdom and age, Matoš's narrator relates a universal grieving experience and for this we feel his equal rather than his subordinate.

\section{Literature}

Allen G.W., 1980, Introduction. Leaves of Grass. By Walt Whitman, New York-Scarborough, p. 5-20.

Alterbaum I., 2003, Listen Speak. Easy in Communication for Second Language Speakers of English, Dubuque, p. 117-344.

Casale F., 2010, Bloom's How to Write About Walt Whitman, New York, p. 43-57.

Donat B., 1986, Matoš - pisac s pogledom na Europu, in: idem, Hodočasnik u labirintu, Zagreb, p. 7-33.

Donat B., 2001, Put kroz noć: antologija poezije hrvatskog ekspresionizma, Zagreb, p. 441-443.

Fletcher A., 2006, The Whitman Phrase, in: Walt Whitman. Bloom's Modern Critical Views, ed. H. Bloom, New York, p. 207-227.

Inness G., 1866, The Valley of the Shadow of Death, <http://www.museuma.com/george-inness/the-valley-of-the-shadow-of-death.html>, 07.05.2014. 
Killingsworth J.M., 2007, The Cambridge Introduction to Walt Whitman, Cambridge, p. $105-122$.

Matoš A.G., 1994, Iz Samobora, in: idem, Putopisi, ed. D. Oraić Tolić, Vinkovci, p. $70-82$.

Matoš A.G., 1997, Utjeha kose, in: idem, Pjesme. Pripovijesti. Putopisi, ed. I. Plejić, Vinkovci, p. 52.

Miller N., 2004, Basic Sonnet Forms, <http://www.sonnets.org/basicforms.htm>, 10.09.2013.

Whitman W., 1892, Death's Valley, <http://www.whitmanarchive.org/ published/perio$\mathrm{dical} /$ poems/per.00028>, 20.09.2013.

Whitman W., 2002, K Whitmanu, in: idem, Vlati trave, prev. i ured. M. Suško, Zagreb, p. 729-772. 